\title{
Profitabilitas Usahatani Sapi Perah Rakyat di Kabupaten Sleman
}

\author{
Shanti Emawati \\ Program Studi Peternakan, Fakultas Pertanian, Universitas Sebelas Maret \\ Jl. Ir. Sutami No. 36A, Surakarta, 57126 \\ Email :shanti_uns@yahoo.co.id
}

\begin{abstract}
ABSTRAK
Penelitian ini bertujuan untuk menentukan profitabilitas atas investasi usahatani sapi perah rakyat di Kabupaten Sleman. Penelitian dilaksanakan pada bulan Juni sampai dengan Juli 2009 dengan lokasi di Kabupaten Sleman. Metode penelitian yang digunakan adalah survei untuk mengumpulkan data primer dari responden dan data sekunder dari dinas terkait serta wawancara dengan menggunakan kuesioner. Responden diambil secara purposive sampling. Analisis finansial untuk menilai profitabilitas atas investasi usahatani sapi perah menggunakan kriteria investasi benefit cost ratio (BCR), net present value (NPV), internal rate of return (IRR) dan payback period (PPC). Hasil analisis finansial berdasarkan umur investasi 5 tahun dengan discount factor 12\%/tahun pada saat ini menunjukkan nilai NPV = Rp. 15.710.080,00; BCR = 2,10; IRR $=41,79 \%$ dan PPC $=2,6$ tahun. Usahatani sapi perah rakyat di Kabupaten Sleman secara finansial layak untuk dijalankan peternak.
\end{abstract}

Kata kunci: sapi perah, usahatani, investasi, profitabilitas

\section{Profitability of Dairy Cattle Farm in Sleman District}

\begin{abstract}
The research was conducted to determine the profitability of investment on dairy cattle farm in Sleman District. Research was done from Juni to July 2009, located in Sleman District. Survey method was done to collect primary data at the farm level and secondary data from related institution and interview with questioner. Purposive sampling was applied to select farmers' respondent. Criteria used to analyze profitability of investment were consisted of Benefit Cost Ratio (BCR), Net Present Value (NPV), Internal Rate of Return (IRR) and Payback Period (PPC). The result of analysis based on 5 years investment and $12 \%$ annual discount factor showed that the value of $N P V=R p .15,710,080.00 ; B C R=2.10$; $I R R=41.79 \%$ and $P P C=2.6$ years. Dairy cattle farm in Sleman District was financially feasible.
\end{abstract}

Key words: dairy cattle, farm, investment, profitability 


\section{PENDAHULUAN}

Di Indonesia pada kurun waktu 5 tahun terakhir pertumbuhan populasi dan produksi susu masing-masing sebesar 7,45\% dan 14,6\%. Jawa Timur merupakan propinsi yang memiliki kontribusi terbesar dalam pertumbuhan dan produksi susu di Indonesia yaitu masing-masing sebesar $14,6 \%$ dan 24,3\% (Soetanto, 2011).

Permasalahan yang dihadapi dalam usaha sapi perah terbagi dalam tiga sektor hulu, tengah dan hilir. Di sector hulu permasalahannya anatra lain produktivitas rendah, bibit sapi perah kurang, biaya pakan tinggi, skala pemilikan rendah dan mutu SDM rendah. Problem di sektor tengah meliputi teknis budidaya dan system recording rendah, ketersediaan lahan untuk produksi pakan menurun, konversi lahan pertanian ke non pertanian, modal usaha dari perbankan masih rendah serta kerjasama lintas sektoral belum terpadu. Di sector hilir antara lain harga susu segar dan konsumen masih rendah serta harga jual pedet/sapi perah tidak stabil (Soetanto, 2011).

Selama ini pemeliharaan sapi perah pada peternak rakyat masih bersifat sederhana, artinya peternak masih menggunakan teknologi yang sederhana dalam pemeliharaan sapi perah, dimana pengetahuan pemeliharaan sapi perah peternak masih didapat secara turuntemurun, dan merupakan usaha sambilan. Setiap usaha mengharapkan keuntungan yang dapat diperoleh dengan menggunakan faktor-faktor produksi yang dimiliki peternak.

Pemerintah telah mengupayakan pengembangan sapi perah dalam rangka untuk meningkatkan produksi dan produktivitas. Upaya tersebut antara lain pemberian kredit sapi perah melalui koperasi dan pemasaran susu diatur melalui industri pengolahan susu (IPS) sejak tahun 19821997 (Gayatri et al., 2005), namun kebijakan sistem perkoperasian sapi perah oleh pemerintah belum menyejahterakan peternak karena kurang memperhatikan strategi manajemen produksi. Berdasarkan hal tersebut, maka permasalahan utama yang perlu dipecahkan adalah bagaimana koperasi sapi perah dalam jangka pendek dapat meningkatkan pendapatan peternak sapi perah. Peningkatan pendapatan peternak erat kaitannya dengan biaya produksi dan manajemen usaha.

Hasil produksi perusahaan sapi perah merupakan hasil gabungan dari berbagai faktor produksi yang digunakan untuk menghasilkan produksi susu. Produksi susu akan optimal apabila penggunaan faktorfaktor produksi dapat dialokasikan secara efisien dengan mengunakan input-input produksi secara optimum. Efisiensi dimaksudkan agar daya guna input produksi rata-rata maksimum sehingga diperoleh keuntungan yang maksimum pula. Berdasarkan latar belakang di atas maka perlu dilakukan penelitian mengenai analisis finansial untuk menilai profitabilitas usahatani sapi perah di Kabupaten Sleman. Tujuan dari penelitian ini adalah untuk menentukan profitabilitas atas investasi usahatani sapi perah rakyat di Kabupaten Sleman.

\section{MATERI DAN METODE}

Penelitian dilaksanakan mulai bulan Juni sampai dengan Juli 2009 dengan lokasi di Kabupaten Sleman. Metode penentuan lokasi penelitian ditentukan secara sengaja, dengan lokasi contoh penelitian di Koperasi UPP Kaliurang dengan pertimbangan bahwa di lokasi tersebut terdapat beberapa kelompok tani ternak yang tergabung dalam Koperasi UPP Kaliurang, Kabupaten Sleman. Metode penelitian yang digunakan adalah survei untuk mengumpulkan data primer dari responden dan data sekunder dari dinas terkait dengan metode pengambilan sampel adalah purposive sampling. Pemilihan secara purposive berarti sampel dipilih dan ditetapkan berdasarkan pertimbangan-pertimbangan tertentu yang sesuai dengan tujuan penelitian (Sugiyono, 2006). 
Analisis Data

Analisis kriteria kelayakan (Becker et al., 2007)

1. Benefit cost ratio (BCR). Rumus yang digunakan :

$$
\mathrm{BCR}=\frac{\text { Discounted gross benefit }}{\text { Discounted total cost }}
$$

(Gittinger, 1986)

Suatu usaha apabila nilai net B/C ratio > 1, maka usaha layak dijalankan, sedangkan untuk nilai net $\mathrm{B} / \mathrm{C}$ ratio $<1$, maka proyek tidak layak dijalankan (Prawirokusumo, 1990).

2. Net present value (NPV). Rumus yang digunakan :

$$
N P V=\sum_{t=1}^{n} \frac{B t-C t}{(1+i)^{t}}
$$

Keterangan :

$\mathrm{B}_{\mathrm{t}}=$ Benefit / keuntungan kotor yang diperoleh pada tahun $\mathrm{t}$

$\mathrm{C}_{\mathrm{t}}=$ Cost / biaya yang dikeluarkan pada tahun $\mathrm{t}$

$\mathrm{i}=$ tingkat diskonto

$\mathrm{n}=$ umur ekonomi proyek (tahun)

Suatu proyek apabila nilai NPV $>0$, maka proyek tersebut layak dijalankan. Jika $\mathrm{NPV}=0$, berarti proyek tersebut mengembalikan persis sebesar social opportunity cost of capital. Jika NPV $<0$, proyek supaya ditolak artinya adanya penggunaan lain yang lebih menguntungkan untuk sumber-sumber yang diperlukan proyek (Kadariah et al., 1999).

3. Internal rate of return (IRR). Rumus yang digunakan :

$$
I R R=i^{\prime}+\frac{N P V^{\prime}}{N P V^{\prime}+N P V^{\prime}} X\left(i^{\prime}{ }^{\prime}-i^{\prime}\right)
$$

(Soekartawi, 2006)
Keterangan :

NPV' = NPV yang positif

NPV" = NPV yang negatif

i'= tingkat bunga yang menghasilkan NPV positif

i” = tingkat bunga yang menghasilkan NPV negatif

Suatu usaha apabila nilai IRR > social discount rate, maka usaha tersebut akan layak dan apabila nilai IRR < social discount rate, maka proyek tersebut tidak akan layak (Pudjosumartono, 1995).

4. Payback period. Rumus yang digunakan untuk menghitung payback period adalah :

Investasi

Rerata net benefit tiap tahun

(Choliq et al., 1999)

\section{Batasan Operasional}

1. Peternak yang diambil sebagai responden adalah petani peternak sapi perah yang berlokasi di Kabupaten Sleman yang memiliki ternak sapi perah minimal 1 ekor sapi laktasi dan telah dipelihara minimal selama 1 tahun

2. Perhitungan analisis finansial ditetapkan dalam jangka waktu selama 5 tahun dengan menggunakan dasar perhitungan proyeksi dari datadata penelitian

3. Perhitungan analisis kelayakan usaha dilakukan dengan penggunaan tingkat bunga (discount rate) 12\% sesuai dengan tingkat bunga yang berlaku pada usahatani ternak tersebut.

4. Nilai yang dimasukkan dalam cash flow hanya merupakan nilai tunai yang ada

5. Tenaga kerja keluarga adalah anggota keluarga yang turut mengelola usaha sapi perah dan tidak dimasukkan dalam perhitungan 
analisis, sehingga pendapatan termasuk opportunity cost dari tenaga kerja keluarga

6. Upah tenaga kerja luar keluarga/sewa dihitung berdasarkan tingkat upah yang berlaku di lokasi penelitian

7. Produksi susu dihitung dari produksi harian kemudian dikonversikan dalam produksi selama satu masa laktasi menurut dasar perhitungan Yapp dan Nevens (1955) cit Pudiarifinanto (2006)

8. Penghitungan satuan ternak dari satuan ekor ke unit ternak menurut Brown (1979) cit Pudiarifinanto (2006) adalah sebagai berikut : a). satu ekor sapi perah betina laktasi yang telah dikawinkan (laktasi/tidak laktasi) dihitung I UT, b). satu ekor sapi perah jantan dewasa berumur 2 tahun dan sudah pernah kawin dihitung 1 UT, c). sapi perah muda atau umur 2 tahun atau lebih dihitung 1 UT, d). sapi perah muda umur 1 tahun hingga 2 tahun dihitung 2/3 UT dan e). sapi perah umur kurang dari 1 tahun dihitung 1/3 UT.

\section{HASIL DAN PEMBAHASAN}

\section{Identitas Peternak}

\section{Umur Peternak}

Umur peternak sapi perah di lokasi penelitian berkisar antara 31 - 70 tahun dengan rata-rata 51 tahun. Umur peternak digolongkan menjadi 3 kelompok yaitu petani taruna yang berusia antara $15-25$ tahun, petani muda yang berusia antara 25 44 tahun dan petani dewasa yang berusia diatas 45 tahun (Soegiharto, 2004). Berdasarkan penelitian bahwa 86,67 \% peternak berusia di atas 45 tahun. Menurut Soegiharto (2004), sektor pertanian menunjukkan tren aging agriculture, yaitu suatu kondisi dimana tenaga kerja yang berada di pertanian adalah tenaga kerja berusia lanjut. Peternak menjadikan ternak sapi sebagai salah satu dari sumber penghidupan dan merupakan komponen dari sistem usahataninya. Sebagian menjadikan ternak sapi sebagai tabungan yang bisa diuangkan sewaktu-waktu, namun ada yang menjadikan ternaknya sebagai salah satu sumber pendapatan yang mendukung perekonomian rumah tangganya. Sifat-sifat usaha yang demikian menyebabkan produktivitas ternak potong tidak dapat berproduksi optimal.

\section{Tingkat pendidikan peternak}

Berdasarkan penelitian menunjukkan bahwa peternak sebagian besar berpendidikan cukup rendah karena 63,33\% mengenyam pendidikan sekolah dasar. Tingkat pendidikan peternak tersebut berpengaruh terhadap manajemen peternakan yang dilakukan. Pendidikan peternak menggambarkan kemampuan mengelola ternak sapi. Menurut Mosher (1987), tingkat pendidikan memiliki peran penting dalam memahami penggunaan teknologi untuk dapat meningkatkan produktivitas usaha pertanian karena dengan semakin tinggi tingkat pendidikan maka akan lebih mudah memahami dan menerapkan teknologi baru. Pendidikan dipandang tidak hanya meningkatkan keahlian dan ketrampilan, melainkan juga dapat memperbaiki sikap dan menambah pengetahuan sumber daya manusia, yang pada akhirnya dapat meningkatkan produktivitas (Sutawi, 2007).

\section{Pekerjaan peternak}

Penduduk di Kabupaten Sleman memiliki jenis pekerjaan beranekaragam. Menurut Sukamdi dan Muntiyah (1997) mengemukakan bahwa di pedesaan masih banyak anggota rumah tangga yang bekerja lebih dari satu jenis pekerjaan artinya mereka mempunyai pekerjaan pokok dan sampingan. Pekerjaan pokok atau pekerjaan utama merupakan mata pencaharian yang membutuhkan waktu curahan kerja yang lebih banyak apabila dibandingkan dengan pekerjaan sampingan (Yoga, 2007). Pekerjaan pokok masyarakat sebagian besar adalah peternak sebesar $70 \%$. Peternak mengusahakan sapi perah untuk membantu 
menambah penghasilan keluarga sehingga dapat meningkatkan taraf hidup peternak.

\section{Aspek Teknis Sapi Perah}

\section{Kandang, pakan dan manajemen pemeliharaan}

Pada umumnya sapi-sapi dipelihara secara intensif yaitu dikandangkan sepanjang hari dengan disediakan pakan yang cukup. Kandang merupakan bagian penting dalam usaha sapi perah. Kandang yang dibangun oleh peternak sapi sangat variatif, mulai dengan yang sangat sederhana, bahan kandang terbuat dari bambu dan kayu sebagai kerangkanya, hingga kandang yang terbuat dari bahan bangunan permanen berdinding batako, namun pada prinsipnya bentuk bangunan kandang hampir sama, didalamnya terdapat tempat pakan pada bagian depan, tempat menyimpan pakan pada bagian sampingnya atau pada bagian atas kandang. Kandang induk dan dara dibangun menjadi satu, tetapi kandang pedet dipisah dari kandang induknya.

Biaya pembuatan kandang bervariasi mulai dari Rp 500.000,00 - Rp 35.000.000,00, tergantung pada kemampuan peternak dan rencana usahanya yang terkait dengan modal. Kapasitas tampung untuk masing-masing kandang umumnya hampir sama yaitu antara $2-6$ ekor ternak dewasa. Sebagian besar ruang pada setiap kandang digunakan sebagai tempat menyimpan pakan, tempat menampung kotoran dan sisa pakan untuk pupuk kandang, sedangkan untuk ternaknya sendiri umumnya hanya menempati ruang sekitar sepertiga bagian kandang.

Setiap peternak mencari pakan $1-2$ kali perhari. Pada pagi dan sore hari peternak umumnya datang ke kandang masing-masing untuk memberikan pakan dan melakukan perawatan lainnya, termasuk mendeteksi birahi. Peternak dalam memberikan pakan, harus mengambil hijauan dari tempat mereka menanamnya. Hijauan berupa rumput Gajah, Kolonjono, Setaria dan rumput Lapangan. Pada musim kemarau, peternak mengganti pakan hijauan dengan limbah pertanian yang dibeli berupa jerami padi atau tebon. Selain itu ternakternak sapi juga diberikan konsentrat berupa dedak, bekatul, dan konsentrat buatan pabrik yang dibeli di kios-kios sapronak seharga Rp 70.000,00-Rp 75.000,00/sak (50 kg).

Pakan yang diberikan pada ternak sapi cukup bervariasi. Pengetahuan tentang pakan diperoleh peternak dari berbagai sumber seperti petugas dari instansi pemerintahan yang pernah memberikan layanan penyuluhan dan adanya proyekproyek bantuan modal ternak yang memberikan informasi tentang pemberian pakan ternak, sehingga hampir sebagian ternak diberi konsentrat, namun demikian pemberian pakan tambahan yang dibeli tergantung pada modal yang mereka miliki. Dilihat dari syarat pemberian pakan, pemberian pakan ternak tidak mempertimbangkan kebutuhan ternak baik secara kualitas maupun kuantitas meskipun mereka juga memberi pakan tambahan berupa konsentrat.

Pemerahan dilakukan dengan menggunakan tangan. Kegiatan pemerahan dilakukan dua kali sehari, yaitu pada pagi hari sekitar jam 05.00 dan siang hari sekitar jam 13.00. Produksi susu yang dihasilkan peternak disetorkan ke koperasi melalui kelompok peternak dan selanjutnya dipasarkan ke Industri Pengolahan Susus (IPS) yaitu PT. Sari Husada.

Pengawasan kesehatan ternak sangat diperlukan agar tidak merugikan peternak. Petenak melakukan pemeriksaan kesehatan secara berkala setiap 3 bulan sekali, 6 bulan sekali atau setahun sekali. Biaya yang dikeluarkan sebesar Rp 3.000,00 - Rp 5.000,00 per peternak. Demikian pula untuk pemeriksaan kebuntingan induk, dilakukan secara berkala.

\section{Calving interval dan service per conception (S/C)}

Calving interval merupakan ukuran kemampuan ternak untuk memberikan hasil berupa pedet. Sapi perah milik peternak rata-rata memiliki jarak beranak (calving 
interval) 15 bulan, dengan rentang antara 14 bulan sampai 20 bulan. Tingginya calving interval tersebut kemungkinan disebabkan oleh kurang baiknya peternak dalam mendeteksi birahi karena jarak rumah peternak dengan lokasi kandang tidak berdekatan. Selain itu, kemungkinan waktu dikawinkan setelah beranak cukup lama.

S/C adalah jumlah perkawinan per kebuntingan. S/C merupakan salah satu komponen biaya dalam usaha sapi perah. Semakin kecil S/C maka biaya semakin besar. S/C pada sapi perah milik anggota koperasi susu Usaha Peternakan dan Pemerahan (UPP) Kaliurang di Kabupaten Sleman adalah 3. Umumnya peternak mengawinkan sapinya dengan cara IB. Keterlambatan penanganan dapat menyebabkan terjadinya kegagalan dalam IB, sehingga untuk menghasilkan kebuntingan 1 ekor induk harus melakukan IB lebih dari 3 kali. Hal tersebut mengakibatkan S/C menjadi tinggi. Oleh karena itu diperlukan peran serta instansi terkait untuk memberikan penyuluhan dalam rangka meningkatkan produktivitas ternak dengan cara memperpendek calving interval dan S/C.

Betina induk umumnya dapat menghasilkan pedet hingga tujuh kali, kemudian peternak akan melakukan replacement. Berdasarkan kondisi biologis tentunya seekor induk memiliki kemampuan berproduksi yang ada batasnya (optimalnya), setelah itu produktivitas akan menurun sejalan dengan umur ternak, bagi peternak yang memiliki induk sapi yang baik, terkadang enggan untuk menjual ternaknya cepat-cepat, karena masih ingin memperoleh produksi susu dan hasil pedet yang baik.

\section{Koefisien Teknis Sapi Perah}

\section{Koefisien teknis}

Koefisien teknis calving interval dan umur penjualan pedet akan berpengaruh pada penerimaan dan biaya produksi (Suzuki et al., 2006). Koefisien teknis usahatani sapi perah pada kondisi peternak anggota koperasi UPP Kaliurang di Kabupaten
Sleman di Kabupaten Sleman dapat dilihat pada Tabel 1.

\section{Profitabilitas Usahatani Sapi Perah}

\section{Profitabilitas atas investasi usahatani sapi perah}

Analisis investasi usahatani pada penelitian ini menggunakan umur investasi 5 tahun. Pada penelitian ini, peternak memelihara induk berkisar antara 2,5 sampai 9 tahun. Lama waktu memelihara induk tergantung kepada kondisi ternak dan kepentingan sosial peternak. Hal ini berarti apabila peternak membutuhkan uang tunai, peternak yang tidak memiliki pedet atau ternak jantan lainnya akan menjual induk miliknya, namun ada juga peternak yang tetap mempertahankan induk miliknya karena memiliki produktivitas yang dirasa cukup baik.

Biasanya ternak dijual untuk keperluan biaya sekolah, biaya pengobatan dan biaya untuk acara keluarga. Diasumsikan umur produktif induk 5 tahun adalah berdasarkan pengalaman peternak untuk induk-induk berkualitas baik dapat mereka pelihara hingga lebih kurang 9 tahun. Berdasarkan kemampuan biologis ternak sapi bahwa seekor sapi betina ratarata memiliki umur afkir kurang lebih 10 tahun (Soekardono, 2006).

\section{Analisis cash flow}

Analisis cash flow memperhitungkan nilai aliran penerimaan uang tunai dan nontunai yang dinilai uangkan dengan opportunity cost (input cash flow) serta aliran biaya yang semua dinilai uangkan (outflow cash flow). Berdasarkan hasil penelitian, nilai cumulatif net cash flow untuk sapi perah cukup tinggi. Hal ini disebabkan tingginya nilai penjualan susu dan sapi perah sehingga menghasilkan keuntungan.

Semakin besar nilai cumulatif net cash flow yang diperoleh menunjukkan bahwa usahatani sapi perah yang dijalankan peternak mendapatkan keuntungan. Tetapi perhitungan tersebut belum dapat digunakan 
Tabel 1. Koefisien teknis usahatani sapi perah pada kondisi peternak anggota koperasi UPP Kaliurang di Kabupaten Sleman di Kabupaten Sleman

\begin{tabular}{lc}
\hline \multicolumn{1}{c}{ Koefisien teknis } & Sapi perah \\
\hline Calving interval & 15 bulan \\
Umur penjualan pedet & 3 bulan \\
\hline
\end{tabular}

Sumber : Data primer terolah, 2009.

sebagai indikator kelayakan usaha karena belum di discount factor. Hasil tersebut hanya menunjukkan bahwa pada periode pemeliharaan tertentu telah dicapai hasil yang positif. Oleh karena itu perlu dilakukan analisis investasi yang memperhitungkan nilai uang di masa mendatang dengan menggunakan discount factor.

\section{Analisis finansial untuk menilai profitabilitas}

Analisis finansial untuk menilai profitabilitas usahatani sapi perah sangat penting dilakukan karena untuk mengetahui apakah usaha yang dijalankan tersebut dalam jangka waktu tertentu dapat mendatangkan keuntungan atau tidak bagi peternak (Pierre et al., 2000). Untuk mengetahui kelayakan usaha digunakan tiga kriteria uji kelayakan yaitu NPV, IRR dan $\mathrm{BCR}$ dengan menggunakan discount rate $12 \%$ dan jangka waktu investasi 5 tahun. Besarnya nilai kriteria finansial usahatani sapi perah di Kabupaten Sleman dapat dilihat pada Tabel 2. Usahatani sapi perah layak dijalankan karena NPV bernilai positif, BCR $>1$ dan IRR $>$ discount factor.

Kriteria NPV. Analisis NPV penting dilakukan karena sejumlah uang tertentu pada saat sekarang mempunyai nilai berbeda dimasa mendatang. NPV merupakan seluruh angka net cash flow yang digandakan dengan discount factor pada tahun dan tingkat bunga yang telah ditentukan (Soekartawi, 2006). Suatu usahatani layak untuk dijalankan apabila NPV bernilai positif.

Penelitian ini menggunakan discount factor $12 \%$ berdasarkan tingkat bunga bank yang berlaku saat penelitian. Nilai NPV usahatani sapi perah pada kondisi peternak anggota koperasi UPP Kaliurang di
Kabupaten Sleman adalah sebesar Rp. 15.710.080,00/5 tahun. Hal ini berarti keuntungan yang diperoleh peternak cukup besar yaitu sebesar Rp. 3.142.016,00/tahun untuk pemeliharaan sapi perah.

Kriteria BCR. BCR merupakan perbandingan antara hasil antara hasil yang dipresent-valuekan dengan biaya modal sebagai indikator bisa diterima atau tidaknya suatu investasi yang dijalankan. Suatu usahatani pembibitan sapi potong layak dijalankan apabila nilai BCR $>1$ (Kadariah et al., 1999). Berdasarkan hasil penelitian, nilai BCR pada usahatani sapi perah pada kondisi peternak anggota koperasi UPP Kaliurang di Kabupaten Sleman bernilai lebih dari satu yang nilainya 2,10. Hal ini berarti usahatani sapi perah layak dijalankan karena penerimaan yang diperoleh peternak lebih besar daripada biaya yang dikeluarkan.

Kriteria IRR. IRR merupakan tingkat keuntungan bersih atas investasi karena benefit bersih yang positif ditanam kembali dalam tahun berikutnya dan mendapatkan tingkat bunga yang sama selama sisa umur proyek (Soekartawi, 2006). Suatu usahatani sapi perah layak dijalankan apabila nilai IRR lebih besar dari $12 \%$ yaitu tingkat bunga (discount rate) yang berlaku saat penelitian. Hasil penelitian menunjukkan bahwa pada usahatani sapi perah pada kondisi peternak anggota koperasi UPP Kaliurang di Kabupaten Sleman memiliki nilai IRR lebih besar dari $12 \%$ yaitu sebesar $41,79 \%$. Hal ini berarti peternak mampu mengembalikan investasi yang ditanamkan.

Payback period. Payback period menunjukkan jangka waktu yang diperlukan untuk mengembalikan seluruh modal yang digunakan pada investasi awal. Apabila payback period tersebut lebih pendek dari 
Tabel 2. Kriteria finansial atas investasi usahatani sapi perah pada kondisi peternak di Kabupaten Sleman

\begin{tabular}{lc}
\hline \hline \multicolumn{1}{c}{ Kriteria finansial } & Nilai kriteria finansial \\
\hline NPV & Rp 15.710.080,00 \\
BCR & 2,10 \\
IRR & $41,79 \%$ \\
Payback period & 2,6 tahun \\
\hline
\end{tabular}

Sumber : Data primer terolah, 2009

umur investasi, maka usaha tersebut menguntungkan sehingga layak untuk dijalankan, namun apabila payback period tersebut lebih panjang dari umur investasi maka usaha tersebut tidak layak dijalankan (Husnan dan Suwarsono, 2005). Berdasarkan penelitian diperoleh bahwa nilai payback period pada usahatani sapi perah pada kondisi peternak anggota koperasi UPP Kaliurang di Kabupaten Sleman yaitu sebesar 2,6 tahun. Hal ini berarti dalam kurun waktu kurang dari tiga tahun dapat mengembalikan investasi sehingga usahatani sapi perah layak dijalankan karena cepat mengembalikan investasi. Menurut Cholig (1999), semakin cepat waktu pengembalian maka semakin baik untuk diusahakan.

\section{KESIMPULAN}

Berdasarkan hasil profitabilitas atas investasi usahatani sapi perah pada kondisi peternak di Kabupaten Sleman dengan menggunakan umur investasi 5 tahun, discount factor $12 \%$ memiliki nilai NPV $=$ Rp 15.710.080,00, IRR $=41,79 \%$, BCR $=$ 2,10 dan payback period $=2,6$ tahun. Berdasarkan hal tersebut menunjukkan bahwa usahatani sapi perah di Kabupaten Sleman layak diusahakan oleh peternak.

\section{DAFTAR PUSTAKA}

Becker, K.M., R.L. Parsons, J. Kolodinsky, G.N. Matirut. 2007. A cost and returns evaluation of alternative dairy products to determine capital investment and operational feasibility of a small-scale dairy processing facility. J.Dairy Sci. 90:2506-2516.

Choliq, A., H.R.A.Wirasasmita dan S. Hasan. 1999. Evaluasi Proyek, Suatu Pengantar. Pioner Jaya. Bandung.

Firman, A. 2007. Kajian Koperasi Persusuan di Jawa Barat. Fakultas Peternakan. Universitas Padjajaran. Bandung.

Gayatri, S., A. Setiadi, Isbandi dan K. Budiraharjo. 2005. Analisis Ekonomi Pemberian Kredit Sapi terhadap Tingkat Pendapatan Peternak Sapi Perah di Kecamatan Pakem Kabupaten Sleman Yogyakarta. Seminar Nasional Teknologi Peternakan dan Veteriner. Semarang.

Gittinger, J.P. 1986. Economic Analysis of Agricultural Projects. UI-Press. Jakarta.

Husnan, S. dan Suwarsono. 2005. Studi Kelayakan Proyek. Fakultas Ekonomi. Universitas Gadjah Mada. Yogyakarta.

Kadariah, L. Karlina dan C. Gray. 1999. Pengantar Evaluasi Proyek. Fakultas Ekonomi. Universitas Indonesia, Jakarta.

Pudiarifinanto, M.R. 2006. Analisis Finansial Usahatani Ternak Sapi Perah berdasarkan Pola Usaha di Desa Glagaharjo Kecamatan Cangkringan Kabupaten Sleman. Skripsi Fakultas Peternakan Universitas Gadjah Mada. Yogyakarta.

St-Pierre, N.R., D. Shoemaker, L.R. Jones. A case study to illustrate analysis of alternative farm investment in fixed assets. 2000. J. Dairy Sci. 83 (5), pp. 1159-1169.

Sugiyono. 2006. Metode Penelitian Bisnis. Cetakan 9. CV Alfabeta. Bandung. Susieni, A. 2003. Studi Kelayakan Bisnis. Cetakan 2. Penerbit Andi. Yogyakarta.

Soekartawi. 2006. Analisis Usahatani. UI-Press. Jakarta. 
Soetanto, H. 2011. Analisis SWOT : Agribisnis Sapi Perah. Makalah Seminar IndoLivestock Expo. Surabaya.

Suzuki, K., M. Kanameda, T. Ogawa, T.T.D. Nguyen, T.T.S. Dang, Q.H. Luu, D.U. Pfeiffer. 2006. Productivity and socioeconomic profile of dairy cattle farmers amongst rural smallholder communities in northern Vietnam. Livestock Science 101 : 242-250.
Yusdja, Y. 2005. Kebijakan Ekonomi Agribisnis Sapi Perah di Indonesia. Analisis Kebijakan Pertanian. Volume 3 no 3. Pusat Analisis dan Kebijakan Pertanian, Bogor

Velasco, J.T., J.A. Ordonez, L.C. Bustillo. Economic sensitivity of a dual-purpose cattle systems due to the variation in average herd reproductive performance. Revista Cientifica de la Facultad de Ciencias Veterinarias de la Universidad del Zulia 10 (1), pp. 30-36. 